\title{
The Logo Analysis from Faculty of Information \\ Technology and Communication of Universitas Semarang in order to Redesign the Logo and the Corporate Identity Design using Logotype Method
}

\author{
Analisis Logo Fakultas Teknologi Informasi dan Komunikasi (FTIK) \\ Universitas Semarang dalam rangka Redesain Logo dan Perancangan \\ Corporate Identity menggunakan Metode Logotype
}

\author{
Firdaus Azwar Ersyad ${ }^{\mathbf{1}}$, Errika Dwi Setya Watie ${ }^{\mathbf{1}}$, Retno Manuhoro Setyowati ${ }^{\mathbf{1}}$ \\ ${ }^{1}$ Study Program of Communication Science, Universitas Semarang, Jl. Soekarno Hatta \\ Tlogosari Semarang 50196, Indonesia \\ *Corresponding author, e-mail: firdaus.azwar@usm.ac.id
}

\begin{abstract}
The logo analysis from Faculty of Information Technology and Communication (FTIK) of Universitas Semarang in order to redesign logo and corporate identity design using logotype method is an effort to stimulate the faculty potentiality, by strengthening the brand image so that faculty is well-known in the future and would convince the society as social partner in organizing education quality. Redesign logo and corporate design is a research and development method which purpose at developing FTIK logo. The research uses Research and Development method. From the entire process of $R \& D$ development, eight steps are taken as follow: Potential and Problems of Data Collection, Product Design, Design Validation, Design Revision, Product Trial, Product Revision, Usage Trial, Mass Production. The process of redesigning the logo and faculty identity design refers to the vision and mission of the faculty so it can be implemented in creative concepts, communication strategies and media.
\end{abstract}

Keywords: Logo Redesign, Corporate Identity, FTIK.

\section{Abstrak}

Analisis Logo Fakultas Teknologi Informasi dan Komunikasi (FTIK) Universitas Semarang dalam rangka redesain logo dan perancangan identitas institusi menggunakan metode logotype merupakan upaya untuk menstimulasi potensi fakultas, dengan memperkuat brand image bahwa fakultas semakin dikenal dan dapat meyakinkan masyarakat sebagai mitra sosial dalam penyelenggaraan program pendidikan yang berkualitas. Redesign logo dan perancangan merupakan penelitian pengembangan yang bertujuan mengembangkan logo FTIK. Penelitian ini menggunakan metode Research and Development. Dari keseluruhan proses pengembangan $R \& D$ diambil delapan langkah sesuai kebutuhan yaitu Potensi dan Masalah Pengumpulan data, Desain Produk, Validasi Desain, Revisi Desain, Uji coba Produk, Revisi Produk, Uji coba Pemakaian, Produksi Massal. Proses mendesain ulang logo dan desain identitas fakultas mengacu visi dan misi fakultas sehingga dapat diimplementasikan dalam konsep kreatif, strategi komunikasi dan media.

Kata Kunci: Redesain Logo, Identitas Institusi, FTIK.

Copyright (C) 2018 Universitas Semarang. All rights reserved.

\section{Introduction}

Progress in the field of science and technology implicate indirectly the way people think how to follow the era progression. One of the progress can be seen in the field of education services, the education promoters trying to make things that can attract the attention of prospective learners to the products offered. As well as universities in 
Indonesia in introducing services and its potentiality, a good identity is needed and should be in line with the institution goals. One of identity form that becomes college representation is the logo.

We can see that the potential market of every university in Indonesia is rising right now, the implication makes those universities, especially private universities, to encourage the implementation of creative marketing strategies in order to attract the public. The creativity efforts are manifested in various ways, one of them is transforming institutional symbols as a new form of innovation.

Universitas Semarang as one of the private universities in Central Java trying to implemented the vision and mission in accordance with the era progression. Therefore, it is important for the institution to change the image into a strong and dynamic brand image. In this research the design of corporate identity initiation begins from one of the faculty that engaged in technology that is the Faculty of Information Technology and Communication (FTIK) of Universitas Semarang.

FTIK, Universitas Semarang is one of the private university with 3 majors, they are Informatics Technology, Information Systems and Communication Science. In Central Java there are many private universities that have computer science faculty and many of them already have their identity. FTIK already has a logo identity as an image that represents the faculty, as shown below:

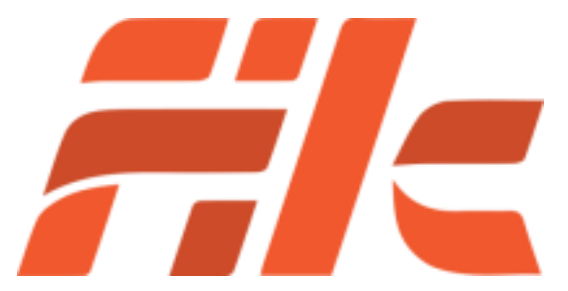

Figure 1. FTIK Logo

(source: FTIK's Website)

The picture above is the logo that is currently become the identity of FTIK, Universitas Semarang. However, from the results of the analysis through initial research before, indicates the logo has lack of legibility, less precise and less representative colors. Thus, it needs a more aesthetic touch to change the faculty identity to be more dynamic. The public images toward faculty can be seen so far from the visual identity of FTIK Universitas Semarang that shown through the logo. In our opinion, the using of logo alone as the FTIK identity is not enough. Moreover, it is important for the institution to have a corporate identity as representation of vision and mission of the faculty. Corporate Identity aim is to communicate corporate identity to the public. A corporate identity has a role to supports the reputation (image). Corporate identity will also be useful for a college (company) in the future which is can form an image and as a promotion media which can givethe college (company) good image on public.

A good and clear and consistent corporate identity or identity will give impact to the brand awareness and positive brand image of the community (Rustan, 2009: 54). In line with the statement of Octaviana talking aboutbranding thatcan not be separated from the basic word 'brand'. Brand is the name, symbol or identity of a product issued by the company to introduce it to the consumers through a process called branding (Octaviana, 2016: 51-56). Therefore, to realize the spirit of change and renewal, FTIK needs to redesign the logo (logo redesign) which has characteristic that formed the faculty vision and mission and providing different identity. 
Redesigning this logo is considered important for many reasons such as launching a new organization, organizing changes corporate culture, and institutional development. A logo derived the meaning from a symbolized quality, through corporate culture, history or aspirations. The meaning of what is meant bythe logo is more important than the appearance. The emphasis is on the meaning beyond the logo form.

The aesthetic touches to redesign the logo and corporate branding of FTIK Universitas Semarang refers to creative strategy using visual communication design approach. It form the branding identity concept that represents the vision mission of the faculty. In addition, logo changes must have unique, memorable, and communicative characteristics that can help the faculty to achieve the goals of strengthening the faculty position and image towards Central Java citizen.

Based on the background of the problems described above, the problem in this study is how to redesign the logo and create the Corporate Identity as a way to enhance Corporate Branding from Faculty of Information Technology and Communication of Universitas Semarang using the Research and Development research method?

\section{Methodology}

The study using Semiotics theory, as Tinarbuko suggests that Semiotics Visual Communication is an effort to provide an interpretation toward semiotics science itself, thussemiotics as a method of viewing visual communication works. In the semiotics the visual communication system attached to the function of communication, means the function of a sign in conveying a message from a sender to the receiver of the sign based on certain rules or codes. The communication function requires a relation between the message sender and recipient, mediated by the particular media (Tinarbuko, 2008: 11).

This research begins with examining the FTIK Logo using Semiotics communication approach, involving various communication elements, such as channels, media, messages, and codes. In the semiotics approach communication emphasizes the "sign production" aspect on the various communication series, channels, and media, rather than "sign systems". The FTIK logo is studied in the communication series, so it has important role in delivering the message to the public. To give meaning the "sign system" would also means that the objects are about to communicate (Nuswantara, 2014: 14-21).

Meanwhile, in giving meaning to sign that will be done, thus will be a basic reference of FTIK logo to redesign the creative process. To design of the results of the analysis would be compare with the conducted data to make the initial concept in logo design and corporate identity.

The logo redesigning and the corporate identity designing uses qualitative research methodology as the research procedure. It was done because the design process requires more indepth information about the FTIK, Universitas Semarang. Based on the results of data collection both literature and data on the field, the data then redesign and design the corporate Identity branding both in terms of selection of media types, visual design elements analyzed based on the qualitative methods and then conclusion obtained. This redesigning logo method using Research and Development (R \& D) proposed by Sugiyono (2010: 56). The method have eight steps: Potential and Problems Data collection, Product Design, Design Validation, Design Revision, Product Trial, Product Revision, Usage Trial, and Mass Production. 


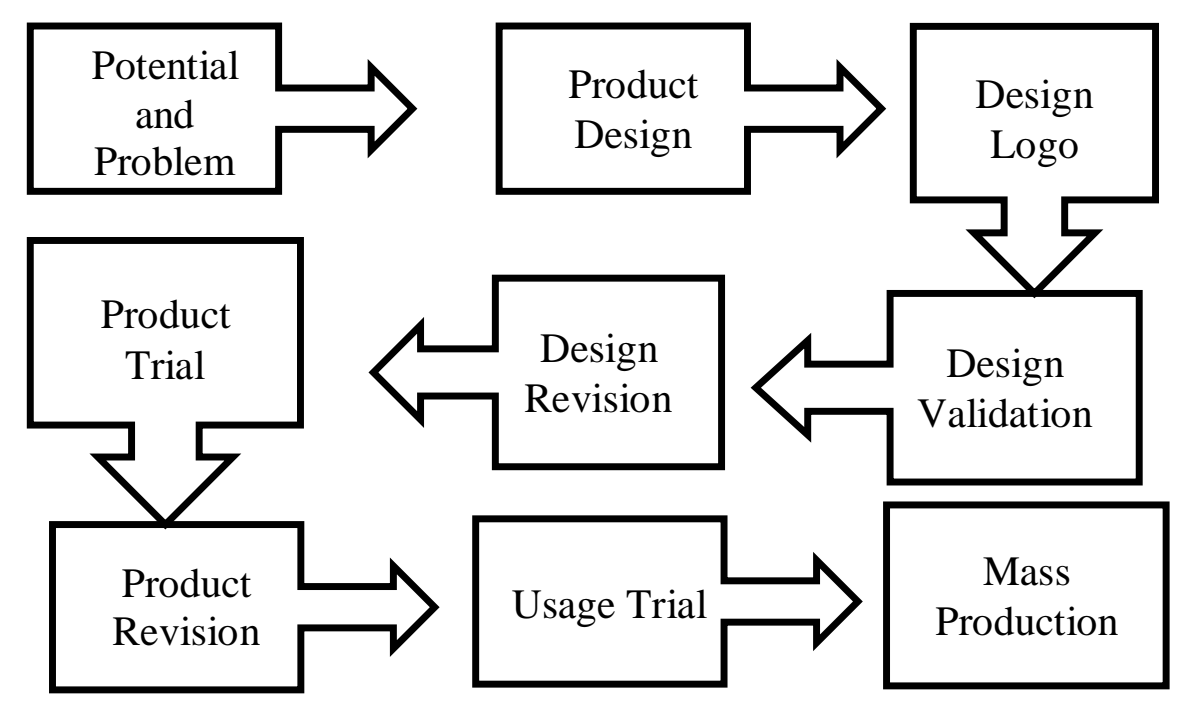

Figure 2. The Map of Concept Research

(source: The results of Researcher Consideration)

In short, the map concept research explanation are:

1. Potentials and problems. Finding the problem of FTIK's visual identity image (logo) using the students and lecturers of FTIK as the target.

2. Data collection. Providing questionnaires to know the research on the existing design, the questionnaire intended as a consideration to determine the design concept and the new logo design visualization.

3. Product Design. Creating a logo design that taken from the questionnaire assessment resultsfrom customers. If there something need to be added then it will be added, if there's something need to reduce from the previous logo then it will be reduce, finally the new FTIK logo design created.

4. Design validation. The process of validating logo that has been made.

5. Design revision. Fixed logo design after know the shortcomings.

6. Design trials. To conduct testing of new logo designs using questionnaires. After that, the logo will be apply in various media for.

7. The final design revision. Make design improvements after knowing the shortcomings during the trial. And this is the final phase on the research.

8. The production of mass products. Once fixed, the final result will be massproduced.

Data collection technique done by interview, observation, documentation and literature study. In this case data collection techniques employ qualitative communication research data. In general, the data in this study can be divided into three types, there are: 1 . the data obtained from interview; 2 . data obtained from observation; 3. the data in the form of documents, texts, or narrated artwork(converted into narrative form). Transcripts of interviews or the conversations with subjects, the records note made during observations, organizational documents or association, those are all includes data. Related to the data collection, there are at least two things that determine the data quality, those are data collection techniques and tools (instrument) that used (Sugiyono, 2010: 59).

Data analysis techniques on the research using Miles and Huberman model analysis, called interactive model technique. The analysis technique consists of three 
components: data reduction, data presentation, and drawing and testing conclusions. On the process of data reduction is not just put away data that is undone, but it is an effort made by researchers during the analysis and those step that can not be separated from data analysis. The data reduction step involves several stages. The first stage involves the steps of editing, grouping, and summarizing data. In the second stage, some codes would be compiles and notes on various things related to the activities and processes so that it several themes, groups, and data patterns could be find and become the material of corporate identity design of the Faculty of Information Technology and Communication (FTIK), Universitas Semarang. Then on the third stage is the preparation of concepts, that would be explain related to the theme or from the data found. After the data found then compiled and reduced to finally get the data presentation. The data presented in the form of data groups, data that are considered important, then would be associated to some theories and after the preparation is done then, the next stage is the drawing and testing the conclusion. The conclusions were made to seek an explanation of some data that has been analyzed which will be used as a basic in drafting the corporate identity concept of FTIK, Universitas Semarang.

\section{Result and Discussion}

Potential problems in FTIK logo design, found on the research using questionnaires, related to the logo. The questionnaires were distributed to the population of the students of morning classes FTIK 2016/2017 as much as 1282 people, with the following distribution: S1 Informatics Engineering students total 608 students; S1 Information System total 326 students; and S1 students of Communication Science total 348 students.

Calculated using the Yamane and Slovin formulas, with 0.05 pesisi level, the questionnaire distributed are 305 questionnaires (O'Sullivan, et.al., 2017: 158). The distribution of questionnaires was done using stratified random sampling technique (Black, 2010: 221 - 222) which resulted in the distribution of questionnaires as follows: S1 Informatics Engineering students 145 students; S1 Information Systems 77 students; and S1 Communication Studies 83 students.

The results of the perception of the characteristics of the FTIK logo are as follows:

\begin{tabular}{|c|c|c|}
\hline Num & Yes & No \\
\hline 1 & 40 & 60 \\
\hline 2 & 43 & 57 \\
\hline 3 & 58 & 42 \\
\hline 4 & 64 & 36 \\
\hline 5 & 34 & 66 \\
\hline 6 & 55 & 45 \\
\hline 7 & 60 & 40 \\
\hline 8 & 23 & 77 \\
\hline 9 & 54 & 46 \\
\hline
\end{tabular}

Table 1. The Results on Percentage of Logo FTIK criterion

The results of the data from the questionnaire above distributed in severalaudiences and the conclusion can be drawn that the colors applied by the FTIK logo is appropriate. But less simple for the level of uniqueness and legibility and uneasy to understand. 
Redesign the FTIK logo, in the creation process requires various stages so that it requires the certain process and stages. The various stages of the logo redesigning techniques include visual design of an idea that the process of designing takes time to look for original ideas to avoid duplication or pre-existing work resembling. Referring to the purpose of the Faculty of Information Technology and Communication (FTIK) of Universitas Semarang goals is to have independence, open, critical, creative, innovative and responsive to national and global changes. The visual image that want to display on the redesign logo is FTIK faculty want draw image better than before. Visual imagethat want to be displayed by the Faculty is simple, fresh, innovative, and unique. Which is appropriate with one of the missions of the FTIK as a resource and a competitive atmosphere to encourage the desire to learn, have analytical thinking, critical and research in Information and Communication Technology to obtain innovations that would give benefit to the society.

After the writer get the results based on the conclusions of the various data, then it followed by making a simple sketchabout the elements that will be used in redesigning the logo.

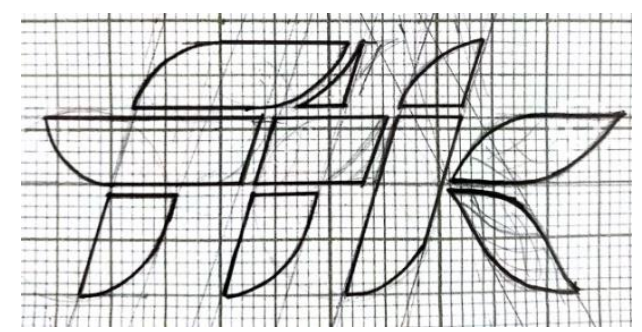

Figure 3. Redesigning Logo Sketch

(source: The results of Researcher Considerations)

After the design of the sketch has been completed, the next step is the process of computerization using the design software as a program of image processing and finishing the design. The results of digital processing design are as follows:

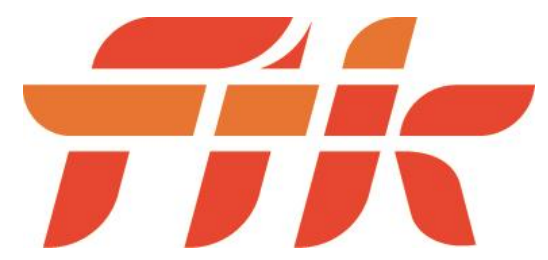

Figure 4. The Result of Logo Redesigning

(source: The results of researcher consideration)

The image above is the result of the creative process after the creation of a sketch design manually. The finished design sketches transformation in digital form are trimmed using design based software. In constructing the logo design the researcher use visual communication semiotics theory. Tinarbuko explains that semiotics visual communication attached to the function of communication, which is used the sign function in conveying message from a sender to the receiver of sign based on certain rules or codes. The communication function requires a relation between the sender and the recipient of the message, mediated by the certain media (Tinarbuko, 2008: 11). The researchers apply the sign system from the logo to see the colors used and the anatomical logo shape. 
The redesign results logo of FTIK still using orange color. Orange classified as a warm color, the psychological color of heat has a positive meaning of spirit, warmth and joy. Orange is a color that represents the enthusiasm of young generation (Eko, 2008: 35-36). In the implementation of color in the FTIK logo is relevant and represents the FTIK has a purpose based on independence, open, critical, creative, innovative and responsive to national and global changes. In addition, in the research, the acceptance of the color applied on the FTIK logo can be accepted positively by the audiences. So that orange color will be keep on the rebranding of FTIK of Universitas Semarang.

As Rustan explained that the logo must be unique, reflect and boost the intensity image. It has been pointed outthat the basic criteria must be seen from several factors such as colors and shapes. In the concept of creating a new FTIK logo, the lines characteristic on the redesign logo is diagonal. The diagonal characterizes the dynamic, active and having certain purpose. It is relevant to the FTIK logo representation that the faculty must move faster and dynamics in line with the development of science and technology. It is formed in line with the trend on the year of 2000 up to now, the logo displays the dynamic impressions, futuristic, using the dull tip concept.

The old FTIK logo, the lessformation of the letters and arrangementif it seen from the letters legibility. In the understanding of typography, kerning (the distance between letters) affects the level of legibility, so on the design of the rebranding logo, kerning must be considered, so that the readability of the logo becomes higher, even applied to small media.

The fonts that use for the old characters of FTIK logo use sans serif letters, which the letters has characters with no hook at the end. The box is angle formed. The letter character is a masculine and have rigid impression. So from the problem explained above, the redesign of logo will have the tip character on the letters, it would made to have serif (hook) at the corner tip of the letter. So it has a more dynamic and less masculine impression. The selected letters on the new design are the old style type, which corresponds to the requirements on the FTIK logo character.

After the stage completed the next thing researcher perform is the stage of analysis, which is the testing stage to assess the logo character from the uniqueness side, simplicity and flexibility. The results of the analysis are as follows:

\begin{tabular}{|c|c|c|}
\hline Num & Yes & No \\
\hline 1 & 20 & 80 \\
\hline 2 & 67 & 33 \\
\hline 3 & 61 & 44 \\
\hline 4 & 70 & 30 \\
\hline 5 & 75 & 25 \\
\hline 6 & 65 & 35 \\
\hline 7 & 72 & 38 \\
\hline 8 & 60 & 40 \\
\hline 9 & 60 & 40 \\
\hline
\end{tabular}

Table 2. The Percentage Result of Design Trial

From the results of the design test data that has been done shows a significant change on the level of simplicity and legibility better than the previous logo. In addition, color combinations that are implemented on the redesigning logo varied using two basic colors of orange and blue. After gaining positive response from audiences the next step is the logo application on the various media. 

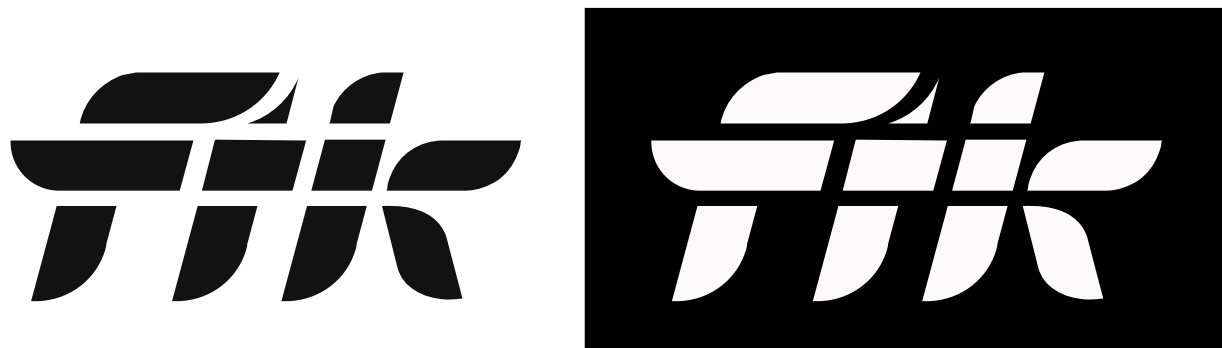

Figure 5. Logo Design in Positive and Diapositive Formats

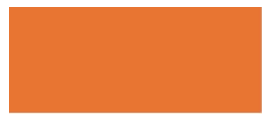

R: 236 G: 120 B: 40

C: 3 M: 65 Y: 97 K: 0

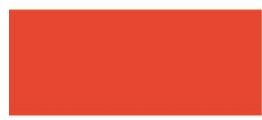

R: 239 G: 67 B: 39

C: 0 M: 89 Y: 96 K: 0

Figure 6. Color Reference

The Application

As the final step is the process of designing corporate identity on the FTIK logo application in various media is as follows:

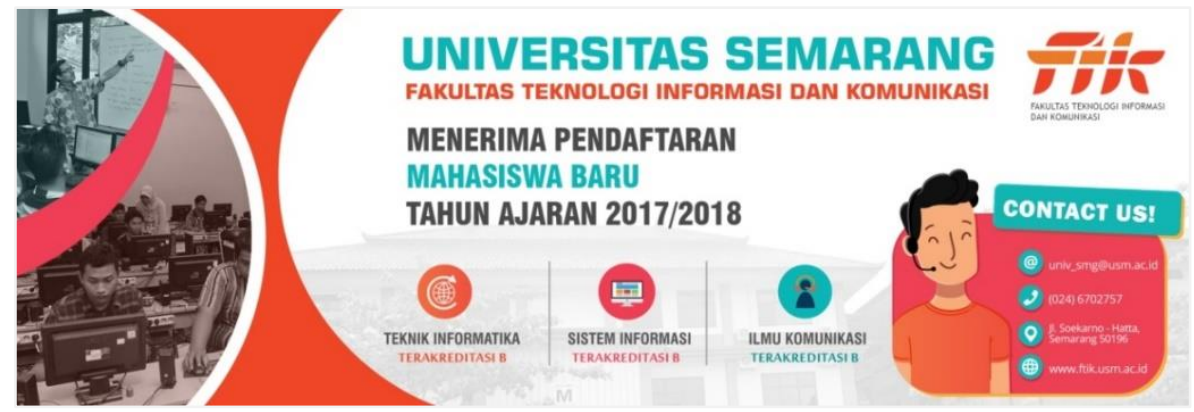

Figure 7. Faculty Banner Design
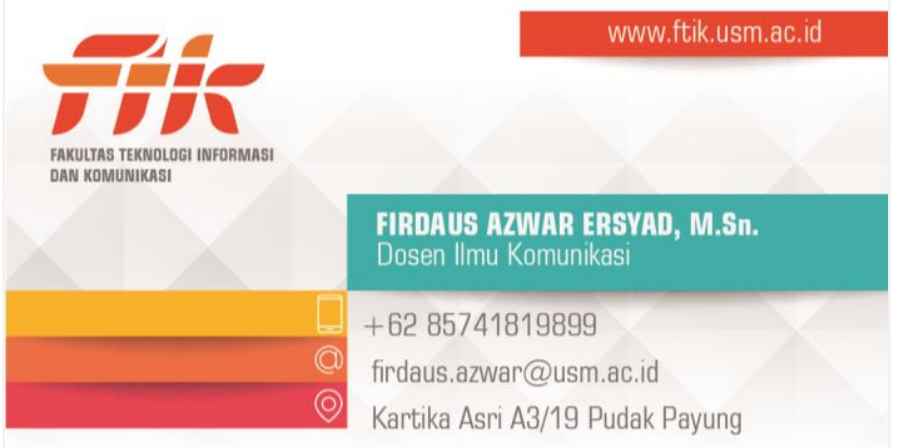

Figure 8. Design a Business Card

\section{Conclusion}

From the results of research and implementation of the work that has been discussed in the previous chapter, the conclusions that can be drawn:

1. The concept of redesigning the logo and design of the corporate identity of the Faculty of Information Technology and Communication (FTIK) is to refer to the objectives of the FTIK of Universitas Semarang which the aim are the independence, openness, critical, creative, innovative and responsive to national and global changes. 
2. Redesigning the logo and designing the corporate identity of FTIK in order to display the better image of the faculty. Visual imagery that want to be displayed by the faculty is simple, fresh, innovative, unique. In accordance with one of the missions of the FTIK is as a resource and a competitive atmosphere to encourage the desire to learn, analytical thinking, critical and research in the field of information and communication technology to obtain innovations that will give benefit to the whole society.

\section{Acknowledgement}

On the research, the authors would like to thank the Institute of Community Service Research (LPPM) at Universitas Semarang who has supported and facilitated the process until the end of the report.

\section{References}

Black, K. (2010). Business Statistics for Contemporary Decision Making. USA: John Wiley \& Sons, Inc.

Nugroho, E. (2008). Pengenalan Teori Warna. Yogyakarya: Andi Offset.

Nuswantara, J.P. (2014). Pesan Sosial dalam Foto Jurnalistik (Analisis Semiotika dalam Buku 'Jakarta Estetika Banal', Bab I, III, V, dan VII). Jurnal The Messenger, 6 (1), 14-21.

Octaviana. (2016). Gambaran Branding Esgrim House Semarang Melalui Media Sosial. Jurnal The Messenger, 8 (1), 51-56.

O’Sullivan, E., Gery Rassel, G., Berner, M., Taliaferro, J. (2017). Research Methods for Public Administrators (Sixth Edition). New York: Routledge.

Rustan, S. (2009). Mendesain Logo. Jakarta : PT.Gramedia Pustaka Utama.

Sugiyono. (2010). Metode Penelitian Kuantitatif, Kualitatif dan R\&D. Bandung: Alfabeta.

Tinarbuko, S. (2009). Semiotika Komunikasi Visual (Edisi Revisi (Cetakan Ketiga)). Yogyakarta: Jalasutra. 